\section{Socioeconomic development, family income, and psychosocial risk factors: a study of families with children in public elementary school}

\author{
Desenvolvimento socioeconômico, renda monetária \\ familiar e fatores de risco psicossociais: um estudo \\ com famílias da rede pública do ensino \\ fundamental
}

\author{
1 Escola Nacional de Saúde \\ Pública Sergio Arouca \\ Fundação Oswaldo Cruz, \\ Rio de Janeiro, Brasil. \\ 2 Instituto de Pesquisa \\ Clínica Evandro Chagas, \\ Fundação Oswaldo Cruz, \\ Rio de Janeiro, Brasil. \\ Correspondence \\ S. G. Assis \\ Centro Latino-Americano de \\ Estudos de Violência e Saúde \\ Jorge Careli, Escola Nacional \\ de Saúde Pública Sergio \\ Arouca, Fundação Oswaldo \\ Cruz. \\ Av. Brasil 4036, sala 700, \\ Rio de Janeiro, $R J$ \\ 21040-361, Brasil. \\ simone@claves.fiocruz.br
}

\begin{abstract}
This article aims to evaluate the effects of Brazil's recent economic growth on the monetary income, consumption patterns, and risk exposures of families with children enrolled in the public elementary school system in São Gonçalo, Rio de Janeiro State, Brazil. The article analyzes the following information on families of 447 children that participated in two waves in a longitudinal study: social stratum, per capita family income, evolution in income over a three-year period, and psychosocial factors. The findings showed $a$ 74.8\% increase in the families' income, accompanied by an increase in the consumption of material assets and access to health services. This increase should not be interpreted as a guarantee of improved living and health conditions, since it was spent on basic products and needs that do not substantially affect the families' form of social inclusion. Psychosocial risk factors were frequent among the families, but decreased during the study period, which may either reflect the improved family situation or result from the later stage in child development.
\end{abstract}

Growth and Development; Social Conditions; Child; Risk Factors
Simone Gonçalves de Assis 1

Thiago Pires 1

Renata Pires Pesce 1

Joviana Quintes Avanci 1

Raquel V. C. Oliveira 2

\section{Introduction}

Recent years have witnessed an improvement in social and economic conditions in Brazil, including a decrease in the inequalities that were so strikingly prevalent until the mid-1990s. According to a study by the Getúlio Vargas Foundation (Fundação Getúlio Vargas) with data from the National Household Sample Survey (PNAD), the proportion of persons below the poverty line was $35.3 \%$ in 1993 , dropping to $18.1 \%$ in 2007 (monthly per capita income less than $\mathrm{R} \$ 121.00$ in 2008 prices) 1 . Factors that contributed to this improvement included the Real Plan, meeting antiinflationary targets, economic growth, minimum wage adjustments, and the adoption of public policies like the Brazilian Income Transfer Program (PBF).

However, although the poverty rate and inequality indicator (Gini index) have improved, there is still a high proportion of poor people in Brazil's metropolitan areas, despite expanded access to public goods and services in the last ten years. This occurred due to the increase in the job supply and policies for education, health, and income transfers that supported the formation of social protection networks, aimed at improving social conditions, even in the context of relative economic deterioration. There was a simultaneous increase in credit and the proportion of the population with bank accounts, in addition to greater effort by government to universalize 
access to basic services like sewage and garbage disposal, water supply, and electricity ${ }^{2}$.

In this sense, Neri ${ }^{3}$ highlights $2003-2008$ as Brazil's "little big decade", characterized by economic growth and a reduction in social inequality. During this phase, consumption of goods and services by the poorest Brazilians grew significantly, suggesting a relatively unexpected situation of transformation of social aspects associated with poverty 2 .

This reality is associated with the fact that since the late first decade of the $21^{\text {st }}$ century, Brazilian families have seen more women in the work market and fewer persons per household (3.3), mainly because the drop in the country's fertility rate, with an average of 1.9 children per woman in 2008 (Instituto Brasileiro de Geografia e Estatística. PNAD: Segurança Alimentar. http:// www.sidra.ibge.gov.br/pnad, accessed on 26/ Apr/2010).

The living and health conditions of children and their families result to a major extent from their socioeconomic status 4 . A hierarchy of determination impacts child development and the health of groups and individuals, ranging from more structural factors (social, economic, and political) to mediations through which these factors exert their influence, especially personal behavior, lifestyles, and community influences 5 .

Growing up under deprived socioeconomic conditions has a negative impact on child development and families' overall health status. Precarious living standards are fertile ground for many psychosocial risk factors, including: reduced social support, stressful life events, depression, difficulties in social competence, low self-esteem and life satisfaction, and problems in the family setting, including violence 6,7. Meanwhile, various stressful events lead to physiological and emotional disruption, increasing the risk of new problems in life and health. Extensive scientific literature has shown that exposure to multiple risks has a heaver negative impact on child development as compared to living with a single risk ${ }^{8,9}$. According to Garmezy 10, the accumulation of family stressors increases the occurrence of childhood psychiatric problems by $33 \%$.

Low-income populations are not only more exposed to adverse, threatening, and dangerous situations, but also tend to receive fewer rewards in the social setting, in addition to experiencing few situations that bring them benefits 11 and interpreting ambiguous events as more stressful, as compared to social strata with higher purchasing power 5,12.

According to Matthews et al. 12, living with recurrent and chronic stress, associated with ge- netic predisposition and risk acquired over life (e.g., precarious health habits), cause accumulated harm to growth and development. These factors, when related to the lowest socioeconomic status and a family and community risk environment, contribute to the maintenance of precarious socioeconomic status and precarious living and health conditions.

This article aims to investigate the impact of Brazil's recent economic growth on family income and the context of multiple risks for families of different wage levels with children enrolled in the public elementary school system. The point of departure is the importance of research on social and economic standards in relation to families and child development.

\section{Materials and methods}

\section{Study population}

This article is based on the analysis of data from families of 447 children that were part of two research waves (2005 and 2008) in a longitudinal study launched with 500 children who were enrolled at the time in the first grade of elementary school in the public school system in São Gonçalo, Rio de Janeiro State, Brazil. A threestage cluster sample design was used: schools, first grade classes, and individual students. The schools were sampled by size-proportional selection, considering the number of students in each school as the adjuvant variable for selecting the classes. Students in the classes were selected by simple random sampling. The 53 children and families that dropped out of the study showed similar characteristics to those analyzed in this article, in terms of gender and mean per capita family income. The following items showed differences between the group that dropped out of the study and the total sample: more losses of children with black and brown skin $(12.1 \%$ and $11.2 \%)$ as compared to white $(9 \% ; \mathrm{p}=0.014)$; and more losses of children without reports of physical violence by the mother or father $(12 \%$ and $13 \%$, respectively; $\mathrm{p} \leq 0.001$ ) as compared to victims of maternal and paternal physical abuse (9.4\% and 7.2, respectively; $\mathrm{p} \leq 0.001$ ).

The data were expanded to the population of students in the municipal public school system, calculating the weight of each student selected for the study, according to the allocation of the sampling units (school, class, and students). Thus, all the students' data were weighted according to the calculated sampling weight, considering all the selection stages. The total number of children used in this article's analysis was 5,966. 
São Gonçalo is the second largest city in the Rio de Janeiro State, with approximately 1 million inhabitants, of whom $7.8 \%$ are 5 to 9 years of age. The city has much more precarious services and infrastructure than the municipality of Rio de Janeiro, with: greater income inequality (Gini index $=0.49)$; lower per capita income $(\mathrm{R} \$ 269.00$ in 2000) and lower average schooling in the population (PNAD: Acesso a Transferências de Renda de Programas Sociais. http://www.sidra.ibge.gov. br, accessed on 26/Apr/2010). The municipality ranks 62 nd in the State's child development index for the year 2004, with a moderate development coefficient (0.721).

The study that gave rise to the article was approved by the Ethics Research Committee of the Brazilian National School of Public Health of the Oswaldo Cruz Foundation (Escola Nacional de Saúde Pública Sergio Arouca, Fundação Oswaldo Cruz - ENSP/Fiocruz), and all the study subjects signed a free and informed consent form.

\section{Measurements used}

The parents or guardians of the selected children were interviewed individually at the school or in exceptional cases at their homes, answering a questionnaire. The child's principal caregiver was the interviewee invited to participate, usually the mother or female guardian, followed by the grandmother, father, and other guardians. Six interviewers with expertise on the issue of childhood violence and with skills for handling interviews were trained and were in charge of contacting the families and conducting the interview, which lasted on average of one hour. The parents/guardians were contacted through an announcement sent with the student from school, or by telephone or telegram.

This article evaluated the following variables, which were applied in both waves (2005 and 2008).

- Social stratum: measured using the Brazilian Economic Classification Criterion (Associação Brasileira de Empresas de Pesquisa. http:// www.abep.org.br, accessed on Jan/2009 and May/2002). This criterion is constructed by assigning scores to the number of household assets (e.g., car, duplex refrigerator or freezer, washing machine) and head-of-family's schooling. In our analysis, the social strata were defined by the same cutoff points 15 in both years in order to compare social mobility. Five social strata (A, B, $\mathrm{C}, \mathrm{D}$, and $\mathrm{E}$ ) were analyzed, with $\mathrm{A}$ as the highest social stratum and $\mathrm{E}$ as the lowest. The classification criterion for 2002 was used, since it was the prevailing criterion at the beginning of the study (2005), with mean income in stratum B ranging from $\mathrm{R} \$ 2,943.00$ to $\mathrm{R} \$ 1,770.00$; from $\mathrm{R} \$ 1,064.00$ to $\mathrm{R} \$ 497.00$ in stratum C; $\mathrm{R} \$ 496.00$ to $\mathrm{R} \$ 263.00$ in stratum D; and from $\mathrm{R} \$ 262.00$ to $\mathrm{R} \$ 0.00$ in stratum E.

- Per capita family income: The household's total income was calculated by adding the income reported by the interviewee for all the individuals that worked and contributed to the child's support, plus other forms of income (PBF conditional cash transfer, pensions, rent, Citizen's Check (income transfer) cash transfer, and others). Per capita family income was then calculated as total family income divided by the number of individuals in the household.

- Evolution of income: defined as the comparison between per capita income for the years 2005 and 2008. The categories were defined according to the family's position in 2005 (per capita family income $\leq 1 / 2$ minimum wage or $>1 / 2$ minimum wage) and the difference between the per capita income for 2008 and 2005 (stable, lower, or higher). The prevailing minimum wage in 2005 was $\mathrm{R} \$ 300.00$. Thus, there were four categories in the income evolution variable: (a) stable or lower $(\leq$ $\mathrm{R} \$ 150.00)$ : income $<1 / 2$ minimum wage in 2005 and stable or lower in 2008; (b) higher ( $\leq \mathrm{R} \$ 150.00$ ): income $<1 / 2$ minimum wage in 2005 and higher in 2008; (c) stable or lower ( $>\mathrm{R} \$ 150.00$ ): income $>1 / 2$ minimum wage in 2005 and stable or lower in 2008; (d) higher (> R \$150.00): income < 1/2 minimum wage in 2005 and higher in 2008.

- Access to health services: item referring to the parent or guardian's need to take the children to a health service (public or private) in the previous year for physical or emotional complaints or illness or to monitor the child's development or for vaccination.

- Stressful life events: 40 items investigated in 2005 and 2008, related to adverse situations in the previous 12 months in the child's living settings (home, school, and neighborhood), such as parents' separation, health problems and death of family members, accidents, floods, or landslides. Other question related to serious physical violence committed by parents or guardians against the child, violence between parents/ guardians (Conflict Tactics Scale 13,14), violence between siblings, and violence in the school and community 15 . All the events were categorized as present or absent. The presence of a given situation was tabulated as one point. The analysis only considered those that answered at least half of all the items. All the items were added and then divided by all the items completed by the respondents in order to construct the score.

- The self-esteem of parents/guardians was measured by the Rosenberg scale 16 , consisting of 10 items that provide a global measurement 
of one's positive or negative self-attitude (for example, whether feeling satisfied with oneself; not having much to be proud of oneself; whether feeling oneself a failure and useless; whether capable of doing things as well as others). The answers were added and distributed in tertiles (high, medium, and low) 17.

\section{Statistical analysis}

SPSS version 16 (SPSS Inc., Chicago, USA) was used to analyze the data. The association between the categorical variables and income variables was verified with the adjusted $\mathrm{F}$ independence test, a variant of the chi-square statistic with second-order Rao-Scott correction.

To compare the variables that quantify household assets (car, refrigerator, etc.) according to income groups and to verify which groups showed differences, the Kruskal-Wallis and Mann-Whitney tests were applied, respectively. Differences in the proportions of life events (yes/no) between the years 2005 and 2008 for each income bracket were verified with the McNemar test. Differences between the continuous variables comparing 2005 and 2008 (number of persons in the household, per capita income, and other sources of income) were analyzed with the Wilcoxon test. P-values $<0.05$ indicated statistically significant differences in the various statistical tests.

\section{Results}

Socioeconomic profile of families and children

The mean age of the children at the beginning of the study (2005) was 8.0 years (standard deviation, $\mathrm{SD}=1.1$ ), increasing to 10.7 years in 2008 $(\mathrm{SD}=1.1)$. In the latter year, there was a slight majority of boys in the sample (50.8\%), comprised mostly of brown or black children (68.2\%).

Table 1 shows the families' profile at baseline and in 2008. The children enrolled in the public school system belonged mostly to low-income families, but with increasing purchasing power. There was no consumption pattern equivalent to that of the highest social stratum (A) and there was a slight reduction in the few families in stratum "B" in the second wave (4\% in 2008). However, analyzing the lower-income strata, there was a major climb from stratum " $\mathrm{D}$ ", migrating to stratum "C" in the three-year period. This improvement appears to have been associated with more schooling for the head-of-family, greater participation by mothers in the work market, and increased income from work and other sources.
Importantly, of all the families, in $2008,64.4 \%$ had other sources of income besides their wages or retirement, like pensions, rent, allowances, and income transfers. Among the families with complementary income, $76 \%$ were enrolled in the Federal government's PBF and $19.1 \%$ received some kind of pension. The number of people in the household remained stable (4.6), although higher than the national average.

The difference in per capita income from 2005 to 2008, shown in Table 1, indicates that most of the families with children in the public school system had a monetary gain $(74.8 \%)$. This financial increase was associated with schooling: among illiterates and those with incomplete elementary schooling, the increase in income was $\mathrm{R} \$ 58.60$ ( $\mathrm{R} \$ 36.80$ to $\mathrm{R} \$ 80.40$ ), while among those with complete elementary schooling and secondary schooling it was $\mathrm{R} \$ 80.10(\mathrm{R} \$ 45.30$ to $\mathrm{R} \$ 115.40)$.

Considering that the evolution in income impacted the families differently according to their 2005 wage levels, Table 2 shows the profile of the different family groups. The child's gender and skin color and father's type of work were distributed equally among all the families, regardless of income evolution during the three-year period. On the other hand, families from social strata B and $\mathrm{C}$, with mothers currently or formerly employed in the formal labor market and with some secondary education (complete or incomplete) were among those with increasing income (independently of their income level in 2005). The far extreme, with the greatest vulnerability, included families with income less than R\$150.00 in 2005 and whose income remained stable or decreased by $2005: 68.1 \%$ of the mothers were either unemployed or worked at home, $62.7 \%$ were heads of families with a maximum of complete elementary schooling, and $36.8 \%$ had consumption patterns consistent with strata D and E. The group of families with an income of R\$150.00 in 2005 and with increasing income during the three-year period showed an intermediate pattern.

The increase in the income of families with children enrolled in the public school system during this three-year period was manifested as more purchases of VCRs and DVD players (an increase of $67.8 \%$ ), duplex refrigerators or freezers $(+45 \%)$, clothes washers $(+15 \%)$, and television sets $(+1.5 \%)$. Subjects were not asked if they owned telephones, although they are a consumer's dream in current Brazilian society; cars, radios, number of bathrooms, and housemaid did not change substantially during the three-year period.

Despite the economic trend, the consumption patterns of families with children in the 
Characteristics of a sample of families with children enrolled in the municipal school system in São Gonçalo, Rio de Janeiro State, Brazil.

\begin{tabular}{|c|c|c|c|c|c|}
\hline \multirow[t]{2}{*}{ Variables/Categories } & \multicolumn{2}{|c|}{2005} & \multicolumn{2}{|c|}{2008} & \multirow[t]{2}{*}{ p-value } \\
\hline & $\mathrm{n}$ & $\%$ & $\mathrm{n}$ & $\%$ & \\
\hline Family's social stratum & & & & & $<0.001$ \\
\hline A & - & - & - & - & \\
\hline B & 267 & 5.4 & 187 & 4 & \\
\hline C & 2,415 & 48.3 & 3,324 & 70.2 & \\
\hline $\mathrm{D}$ & 2,282 & 45.6 & 1,199 & 25.3 & \\
\hline$E$ & 40 & 0.8 & 27 & 0.6 & \\
\hline Schooling, head of family & & & & & $<0.001$ \\
\hline Illiterate/Incomplete primary & 2,358 & 47.1 & 1,586 & 26.6 & \\
\hline Complete primary & 695 & 13.9 & 1,774 & 29.7 & \\
\hline Incomplete secondary or greater & 1,951 & 39 & 2,606 & 43.7 & \\
\hline Type of work, mother/guardian & & & & & $<0.001$ \\
\hline Employee, employer, or retired & 1,535 & 27.1 & 2,002 & 33.8 & \\
\hline Self-employed & 1,482 & 26.2 & 1,723 & 29.1 & \\
\hline Unemployed or housework & 2,640 & 46.7 & 2,200 & 37.1 & \\
\hline Type of work, father/guardian & & & & & $<0.001$ \\
\hline Employee, employer, or retired & 2,951 & 64.8 & 3,138 & 62.2 & \\
\hline Self-employed & 1,321 & 29 & 1,545 & 30.6 & \\
\hline Unemployed or housework & 279 & 6.1 & 361 & 7.1 & \\
\hline Number of persons in household & & & & & 0.106 \\
\hline Mean * $(95 \% \mathrm{Cl})$ & 5,966 & $4.7(4.5-4.8)$ & 5,966 & $4.6(4.5-4.8)$ & \\
\hline Per capita family income & & & & & $<0.001$ \\
\hline Mean * $(95 \% \mathrm{Cl})$ & 5,926 & $\begin{array}{c}\mathrm{R} \$ 138.00 \\
(\mathrm{R} \$ 125.20-\mathrm{R} \$ 151.60)\end{array}$ & 5,860 & $\begin{array}{c}\mathrm{R} \$ 211.20 \\
(\mathrm{R} \$ 188.80-\mathrm{R} \$ 233.70)\end{array}$ & \\
\hline $\begin{array}{l}\text { Other income (social programs, rent, } \\
\text { etc.) }\end{array}$ & & & & & $<0.001$ \\
\hline Mean * $(95 \% \mathrm{Cl})$ & 3,202 & $\begin{array}{c}\mathrm{R} \$ 146.60 \\
(\mathrm{R} \$ 121.70-\mathrm{R} \$ 171.40)\end{array}$ & 3,790 & $\begin{array}{c}R \$ 211.20 \\
(R \$ 141.00-R \$ 281.40)\end{array}$ & \\
\hline \multicolumn{6}{|l|}{ Difference in per capita income from } \\
\hline \multicolumn{6}{|l|}{2005 to 2008} \\
\hline$<\mathrm{R} \$ 0.00$ & - & - & 1,468 & 25.2 & - \\
\hline$\leq \mathrm{R} \$ 49.00$ & - & - & 1,361 & 23.4 & \\
\hline $\mathrm{R} \$ 50.00$ to $\mathrm{R} \$ 99.00$ & - & - & 1,267 & 21.8 & \\
\hline$\geq R \$ 100.00$ & - & - & 1,723 & 29.6 & \\
\hline
\end{tabular}

95\%Cl: $95 \%$ confidence interval.

* $95 \% \mathrm{Cl}$ for the mean.

public school system was still low in 2008: television sets and bathrooms were the only items reported by nearly all of the families (98\% and 99\%), followed by radios (88.8\%), VCRs/DVD players (77.7\%), refrigerators without freezer compartments (74.9\%), washing machines (62\%), and duplex refrigerators or freezers (36.2\%). Only $13.2 \%$ of the families had cars and $1.3 \%$ had housemaids.

Table 3 shows the low consumption pattern for different family groups according to the evolution in per capita income from 2005 to 2008 . The table particularly highlights the economic vulnerability of the group with income of $\mathrm{R} \$ 150.00$ and stable or downward income, with lower ownership of duplex refrigerators, clothes washers, radios, TV sets, and VCRs/DVD players. The group with upward income and a baseline per capita income greater than $\mathrm{R} \$ 150.00$ in 2005 showed the highest purchasing power during the three-year period, including more car ownership.

Access to health services also differed among the families. Parents were asked to report on the need to take the child to a health service 
Profile of different family groups according to evolution in per capita income from 2005 to 2008.

\begin{tabular}{|c|c|c|c|c|c|c|c|c|c|}
\hline \multirow[t]{3}{*}{ Variables/Categories } & & & \multicolumn{4}{|c|}{ Evolution in income (2005-2008) } & & & \multirow[t]{3}{*}{$p$-value } \\
\hline & \multicolumn{2}{|c|}{$\begin{array}{l}\text { Stable or lower } \\
(\leq \mathrm{R} \$ 150.00)\end{array}$} & \multicolumn{2}{|c|}{$\begin{array}{c}\text { Higher } \\
\text { (s R } \$ 150.00)\end{array}$} & \multicolumn{2}{|c|}{$\begin{array}{l}\text { Stable or lower } \\
\text { (> R\$150.00) }\end{array}$} & \multicolumn{2}{|c|}{$\begin{array}{c}\text { Higher } \\
\text { (> R\$150.00) }\end{array}$} & \\
\hline & $\mathrm{n}$ & $\%$ & $\mathrm{n}$ & $\%$ & $\mathrm{n}$ & $\%$ & $\mathrm{n}$ & $\%$ & \\
\hline Child's gender & & & & & & & & & 0.495 \\
\hline Male & 387 & 56.9 & 1,589 & 47.6 & 467 & 56.4 & 521 & 53.4 & \\
\hline Female & 293 & 43.1 & 1,747 & 52.4 & 361 & 43.6 & 455 & 46.6 & \\
\hline Child's skin color & & & & & & & & & 0.097 \\
\hline White & 214 & 31.4 & 921 & 27.8 & 321 & 38.8 & 388 & 39.8 & \\
\hline Brown/black & 467 & 68.6 & 2,389 & 72.2 & 507 & 61.2 & 588 & 60.2 & \\
\hline Family's social stratum & & & & & & & & & 0.001 \\
\hline $\mathrm{B}$ & 0 & 0 & 53 & 2.1 & 40 & 5.9 & 94 & 10.5 & \\
\hline C & 320 & 63.2 & 1,668 & 65.8 & 507 & 74.5 & 761 & 85 & \\
\hline $\mathrm{D}+\mathrm{E}$ & 187 & 36.8 & 813 & 32.1 & 133 & 19.6 & 40 & 4.5 & \\
\hline Schooling, head of family & & & & & & & & & 0.001 \\
\hline Illiterate/Incomplete primary & 227 & 33.3 & 960 & 28.8 & 160 & 19.4 & 173 & 17.8 & \\
\hline Complete primary & 200 & 29.4 & 1,174 & 35.2 & 213 & 25.8 & 147 & 15.1 & \\
\hline $\begin{array}{l}\text { Incomplete secondary or } \\
\text { greater }\end{array}$ & 254 & 37.3 & 1,202 & 36 & 454 & 54.9 & 656 & 67.2 & \\
\hline Type of work, mother & & & & & & & & & 0.000 \\
\hline Employee/Employer/Retired & 80 & 12 & 1,068 & 32.3 & 348 & 42 & 467 & 47.9 & \\
\hline Self-employed & 133 & 20 & 1,121 & 33.9 & 174 & 21 & 281 & 28.8 & \\
\hline Unemployed or housework & 454 & 68.1 & 1,120 & 33.8 & 307 & 37 & 227 & 23.3 & \\
\hline Type of work, father & & & & & & & & & 0.092 \\
\hline Employee/Employer/Retired & 307 & 53.5 & 1,669 & 61.3 & 415 & 58.6 & 681 & 75 & \\
\hline Self-employed & 226 & 39.5 & 826 & 30.3 & 199 & 28.2 & 227 & 25 & \\
\hline Unemployed or housework & 40 & 7 & 227 & 8.3 & 94 & 13.2 & 0 & 0 & \\
\hline
\end{tabular}

during the previous year for physical or emotional complaints or illnesses or to monitor their growth and development and for vaccination. The groups that most sought for attendance for health were those with upward income $(69.5 \%$ of those that earned less than R\$150.00 in 2005 and $60.3 \%$ among the families with per capita income greater than $\mathrm{R} \$ 150.00)$; lower use of health services was observed among some $53 \%$ of the families with stable or downward per capita income $(\mathrm{p}=0.066)$.

\section{Psychosocial risk factors according to socioeconomic strata}

On average, families with children in the public school system in 2005 experienced $12.2(\mathrm{SD}=8.1)$ risk factors with the potential to affect child development, a figure which decreased to 9.5 (SD = $7.0 ; \mathrm{p}<0.001$ ) in 2008.
In 2005 and 2008, adverse psychosocial events were similar in different types of families, with the exception of parental unemployment, serious family problems, and household crowding with insufficient space, which were mentioned more frequently by lower-income families.

Table 4 allows analyzing the events mentioned by the families in 2005 and 2008 from a different angle, prioritizing the changes in each family group during the year prior to the study. In general, the events occurred in all groups of families, without a definite pattern. The family events generally decreased over the course of the three-year period, with some exceptions, like the increase in the number of family members arrested or indicted in the lower-income strata in 2005 and the death of family members and substance abuse problems in the group with upward income and per capita income greater than $\mathrm{R} \$ 150.00$ in 2005. 
Consumption patterns of different family groups according to evolution in per capita income from 2005 to 2008.

\begin{tabular}{|c|c|c|c|c|c|c|c|c|c|}
\hline \multirow[t]{3}{*}{ Assets } & \multicolumn{8}{|c|}{ Evolution in income $(2005-2008)$} & \multirow[t]{3}{*}{$\mathrm{p}$-value } \\
\hline & \multicolumn{2}{|c|}{$\begin{array}{l}\text { Stable or lower } \\
(\leq \mathrm{R} \$ 150.00)\end{array}$} & \multicolumn{2}{|c|}{$\begin{array}{c}\text { Higher } \\
(\leq \mathrm{R} \$ 150.00)\end{array}$} & \multicolumn{2}{|c|}{$\begin{array}{c}\text { Stable or lower } \\
\text { (> R\$150.00) }\end{array}$} & \multicolumn{2}{|c|}{$\begin{array}{c}\text { Higher } \\
\text { (> R\$150.00) }\end{array}$} & \\
\hline & Mean & $95 \% \mathrm{Cl}$ & Mean & $95 \% \mathrm{Cl}$ & Mean & $95 \% \mathrm{Cl}$ & Mean & $95 \% \mathrm{Cl}$ & \\
\hline Car & 0.1 & $0.09-0.14$ & 0.1 * & $0.09-0.11$ & 0.1 * & $0.09-0.13$ & $0.3 * \star, \star \star \star *$ & $0.23-0.29$ & 0.010 \\
\hline Bathroom & 1.1 & $1.06-1.10$ & 1.1 * & $1.07-1.09$ & 1.0 * & $0.00-1.04$ & $1.2 * \star, \star \star \star$ & $1.18-1.26$ & 0.057 \\
\hline Domestic servant & 0.0 & $0.01-0.03$ & $0.0 * \star \star$ & $0.00-0.01$ & 0.0 ** & $0.02-0.04$ & 0.0 & $0.02-0.04$ & 0.2180 \\
\hline $\begin{array}{l}\text { Refrigerator without } \\
\text { freezer }\end{array}$ & 0.1 & $0.08-0.85$ & 0.8 & $0.77-0.80$ & 0.1 & $0.66-0.73$ & 0.7 & $0.64-0.70$ & 0.1120 \\
\hline $\begin{array}{l}\text { Duplex refrigerator or } \\
\text { freezer }\end{array}$ & $0.0 *, \star \star \star$ & $0.24-0.31$ & 0.3 * & $0.39-0.35$ & $0.5 \#$ & $0.43-0.50$ & $0.5 * *$, \# & $0.46-0.53$ & 0.0220 \\
\hline Clothes washer & 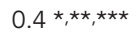 & $0.39-0.47$ & $0.6 * \#$ & $0.58-0.61$ & $0.6 *$ *\# & $0.60-0.66$ & $0.9 * \star, * \star *, \#$ & $0.87-0.91$ & 0.0000 \\
\hline Radio & $0.8 *, * \star * * \star *$ & $0.77-0.83$ & $1.0 *, \star \star \star, \#$ & $0.95-.98$ & $1.1 *, \star \star, \#$ & $1.05-1.11$ & $1.3 * \star, \star \star *$ & $1.25-1.33$ & 0.0000 \\
\hline Television set & 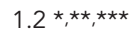 & $1.14-1.22$ & $1.4 *$ * \# & $1.39-1.43$ & $1.4 *$ & $1.39-1.48$ & 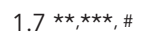 & $1.66-1.76$ & 0.0000 \\
\hline VCR/DVD player & 1.4 * & $1.34-1.48$ & 1.5 * & $1.45-1.51$ & 1.6 * & $1.53-1.64$ & $1.9 * \star, \star \star \star, \#$ & $1.86-1.92$ & 0.0010 \\
\hline
\end{tabular}

95\% Cl: 95\% confidence interval.

* Significant difference at 0.05 for the higher income group (> R\$150.00);

** Significant difference at 0.05 for the higher income group $(\leq \mathrm{R} \$ 150.00)$;

*** Significant difference at 0.05 for the stable or lower income group (> R\$150.00);

\# Significant difference at 0.05 for the stable or lower income group ( $\leq \mathrm{R} \$ 150.00$ ).

The group of accidents showed a particularly high number of motor vehicle accidents. There was a decrease in accidents in the school among all the groups of families, but in the families' residential neighborhoods there was an increase in the following: contact with firearms (especially in groups with lower income in 2005), witnessing robberies and people getting injured or murdered, having one's own home burglarized, and witnessing dangerous situations in the neighborhood.

Household violence decreased during the period in all groups.

\section{Parental self-esteem according to social stratum}

The parents/guardians of children with per capita family income less than $\mathrm{R} \$ 150.00$ in 2005 were those with the lowest self-esteem in 2006 (45\% of those with stable or downward income and $36 \%$ of those with upward income). Among families with per capita income greater than $\mathrm{R} \$ 150.00$ in 2005 , the parent or guardian reported significantly fewer self-steem (14.3\% among those with stable or downward income and $24.1 \%$ among those with upward income; $\mathrm{p}=0.012)$.

\section{Discussion}

The study's findings, portraying the reality of a large city in the Rio de Janeiro State, foster reflection on changes in recent years in the living and health conditions of children enrolled in the public school system in Brazil as a whole.

First, the results indicate that from 2005 to 2008, $74.8 \%$ of the families with children enrolled in the São Gonçalo municipal school system experienced an increase in their income, accompanied by a rise in the consumption of material goods and access to health services. This monetary increase may have been favored by greater access to income transfers from social programs in the Rio de Janeiro State. In the State, $6 \%$ of the private households in 2006 received cash from government social programs, and $8.6 \%$ of the persons residing in private households were assisted by such programs (PNAD: Acesso a Transferência de Renda de Programas Sociais. http:/ / www.sidra. ibge.org.br, accessed on 26/Apr/2010). These data corroborate the degree of vulnerability of families with children enrolled in the public school system in São Gonçalo, where $64.4 \%$ of the families receive such forms of income redistribution.

However, the increase in family income should not be interpreted as a guarantee of 
Psychosocial risk factors according to evolution in per capita income from 2005 to 2008 *.

\begin{tabular}{|c|c|c|c|c|c|}
\hline \multirow[t]{2}{*}{ Events } & \multirow[t]{2}{*}{ Year } & \multicolumn{4}{|c|}{ Evolution in income \% (2005-2008) } \\
\hline & & $\begin{array}{l}\text { Stable/lower } \\
\text { (< R\$150.00) }\end{array}$ & $\begin{array}{c}\text { Higher } \\
(<\mathrm{R} \$ 150.00)\end{array}$ & $\begin{array}{l}\text { Stable/lower } \\
(>\mathrm{R} \$ 150.00)\end{array}$ & $\begin{array}{c}\text { Higher } \\
\text { (> R\$150.00) }\end{array}$ \\
\hline \multicolumn{6}{|l|}{ Family events } \\
\hline \multirow[t]{2}{*}{ Unemployment, one parent } & 2005 & 79.0 * & 84.0 * & 73.3 * & 51.2 * \\
\hline & 2008 & 58.8 & 50.8 & 40.2 & 23.6 \\
\hline \multirow[t]{2}{*}{ Serious financial problems in family } & 2005 & 57.1 & 55.9 * & 31.9 * & 24.1 \\
\hline & 2008 & 60.7 & 43.1 & 35.3 & 35.5 \\
\hline \multirow[t]{2}{*}{ Household crowding, lack of space } & 2005 & 29.8 * & 30.0 * & 12.0 & 8.9 \\
\hline & 2008 & 17.7 & 26.5 & 14.6 & 5.5 \\
\hline \multirow[t]{2}{*}{ Family member arrested or indicted } & 2005 & 14.3 * & 9.2 * & 7.8 & 10.3 \\
\hline & 2008 & 15.7 & 10.1 & 11.5 & 9.6 \\
\hline Death of child's father, mother, or & 2005 & 4.3 & $1.8 *$ & 1.8 & 1.4 * \\
\hline sibling & 2008 & 5.9 & 4.4 & 1.6 & 5.4 \\
\hline \multirow[t]{2}{*}{ Alcohol or drug problems in family } & 2005 & 26.3 & 25.4 * & 25.4 * & 17.0 * \\
\hline & 2008 & 29.5 & 23 & 19.6 & 19.5 \\
\hline Arguments among family involving & 2005 & 17.1 * & 25.3 & 28.2 * & 36.5 * \\
\hline the children & 2008 & 13.8 & 25 & 22.6 & 20.5 \\
\hline \multirow[t]{2}{*}{ Parents' divorce } & 2005 & 9.5 & 18.2 * & 6.5 & 18.7 * \\
\hline & 2008 & 3.9 & 8.1 & 9.7 & 5.5 \\
\hline \multirow[t]{2}{*}{ Father/mother remarried } & 2005 & $16.1 *$ & 14.4 * & $15.0 *$ & 5.1 \\
\hline & 2008 & 3.9 & 8.9 & 3.2 & 9.6 \\
\hline \multirow[t]{2}{*}{ Child or family member kidnapped } & 2005 & - & 1.2 & - & 1.4 \\
\hline & 2008 & 1.9 & - & - & - \\
\hline Child or family member experienced & 2005 & $11.1 *$ & 14.9 * & 10.9 & 12.1 * \\
\hline $\begin{array}{l}\text { very painful or frightening medical } \\
\text { treatment }\end{array}$ & 2008 & 5.7 & 2.3 & 4.8 & 5.9 * \\
\hline \multirow[t]{2}{*}{ Child hospitalized } & 2005 & 2.9 & 16.0 * & 12.6 * & 11.3 * \\
\hline & 2008 & - & 4.8 & 1.6 & 2.8 \\
\hline \multicolumn{6}{|l|}{ Accidents } \\
\hline Child suffered serious car or bus & 2005 & 4.0 & 2.9 * & $1.7 *$ & 4.3 * \\
\hline accident & 2008 & 5.9 & 4.4 & 3.2 & 8.2 \\
\hline \multirow[t]{2}{*}{ Child experienced landslide/cave-in } & 2005 & 6.1 & 1.2 * & 3.3 * & 1.4 \\
\hline & 2008 & - & 0.4 & 1.6 & - \\
\hline \multirow[t]{2}{*}{ Child experienced serious flood } & 2005 & 10.0 * & 10.6 * & 1.7 & 4.3 * \\
\hline & 2008 & 2.0 & 5.2 & 1.6 & 1.4 \\
\hline \multirow[t]{2}{*}{ Child experienced serious fire } & 2005 & 4.0 & 1.2 & $1.6 *$ & 1.4 \\
\hline & 2008 & - & 1.2 & 3.2 & 1.4 \\
\hline
\end{tabular}

(continues) 
Table 4 (continued)

\begin{tabular}{|c|c|c|c|c|c|}
\hline \multirow[t]{2}{*}{ Events } & \multirow[t]{2}{*}{ Year } & \multicolumn{4}{|c|}{ Evolution in income \% (2005-2008) } \\
\hline & & $\begin{array}{l}\text { Stable/lower } \\
(<R \$ 150.00)\end{array}$ & $\begin{array}{c}\text { Higher } \\
(<\mathrm{R} \$ 150.00)\end{array}$ & $\begin{array}{l}\text { Stable/lower } \\
(>\mathrm{R} \$ 150.00)\end{array}$ & $\begin{array}{c}\text { Higher } \\
(>\mathrm{R} \$ 150.00)\end{array}$ \\
\hline \multicolumn{6}{|l|}{ Events at school } \\
\hline \multirow[t]{2}{*}{ Child threatened at school } & 2005 & 11.8 * & 10.8 * & 8.0 & 15.0 * \\
\hline & 2008 & 5.9 & 5.7 & 8.3 & 6.8 \\
\hline Child assaulted at school to the point & 2005 & 2.0 & $2.4^{*}$ & - & 5.5 * \\
\hline of requiring bandage or visit to doctor & 2008 & 1.9 & 0.8 & 5.0 & 1.4 \\
\hline Child's belongings damaged & 2005 & 9.9 * & 11.7 * & 9.8 * & 12.4 * \\
\hline intentionally at school & 2008 & 2.0 & 2.8 & 1.7 & 5.5 \\
\hline Child had contact in school with & 2005 & - & - & 1.6 & - \\
\hline persons bearing firearms & 2008 & - & 0.8 & 1.6 & - \\
\hline Child had contact in school with & 2005 & - & - & 1.6 & 1.4 \\
\hline persons bearing knives & 2008 & - & 0.8 & 1.6 & - \\
\hline \multirow[t]{2}{*}{ Child's belongings stolen at school } & 2005 & 23.6 * & 18.6 * & 22.5 * & 32.8 * \\
\hline & 2008 & 2.0 & 12.5 & 8.4 & 12.4 \\
\hline Child's belongings robbed by force & 2005 & 3.9 & 2.4 * & 1.6 & 4.1 \\
\hline at school & 2008 & - & 0.4 & - & - \\
\hline \multicolumn{6}{|l|}{ Events in neighborhood } \\
\hline \multirow[t]{2}{*}{ Child threatened in the neighborhood } & 2005 & 5.9 & 6.0 & 4.8 & 2.8 \\
\hline & 2008 & 5.9 & 5.2 & 4.8 & 4.1 \\
\hline Child assaulted in the neighborhood & 2005 & 5.9 & 1.6 & 3.2 & 2.8 \\
\hline $\begin{array}{l}\text { to the point of requiring bandage or } \\
\text { visit to doctor }\end{array}$ & 2008 & - & 1.6 & 3.2 & 2.7 \\
\hline Child's belongings damaged & 2005 & 7.9 & 7.3 * & 6.5 & 8.3 \\
\hline intentionally in neighborhood & 2008 & - & 3.6 & 6.5 & - \\
\hline Child had contact in the & 2005 & 2.0 * & 3.2 & - & 1.4 \\
\hline \multicolumn{6}{|l|}{ firearms } \\
\hline Child had contact in the & 2005 & - & 0.4 * & - & - \\
\hline $\begin{array}{l}\text { neighborhood with persons bearing } \\
\text { knives }\end{array}$ & \multicolumn{4}{|c|}{ knives } & 1.4 \\
\hline Child's belongings stolen in the & 2005 & 3.9 & 6.5 * & 4.9 * & 4.1 \\
\hline neighborhood & 2008 & 3.9 & 3.2 & 1.6 & 2.7 \\
\hline Child's belongings robbed by force in & 2005 & 3.9 * & 1.2 & 1.6 & 2.7 * \\
\hline the neighborhood & 2008 & 2.0 & 1.6 & & 1.4 \\
\hline Child experienced dangerous & 2005 & 6.0 * & 12.2 & 13.3 & 7.3 * \\
\hline situation in the neighborhood & 2008 & 12.0 & 12.2 & 11.4 & 14.3 \\
\hline \multirow[t]{2}{*}{ Child's home was burglarized } & 2005 & - & 1.2 * & - & - \\
\hline & 2008 & - & 2.5 & 1.6 & - \\
\hline Child saw someone rob or shoot & 2005 & $6.0 *$ & 10.8 * & 5.0 * & 7.4 * \\
\hline someone else & 2008 & 2.0 & 5.5 & 8.2 & 7.0 \\
\hline \multirow[t]{2}{*}{ Child saw persons being killed } & 2005 & 4.1 & 10.0 * & 8.8 & 2.9 * \\
\hline & 2008 & 4.0 & 6.8 & 8.2 & 10.0 \\
\hline Child saw someone being serious & 2005 & 8.2 & 6.4 * & 4.9 * & 4.2 * \\
\hline wounded & 2008 & 8.0 & 9.6 & 9.8 & 11.3 \\
\hline
\end{tabular}

(continues) 
Table 4 (continued)

\begin{tabular}{|c|c|c|c|c|c|}
\hline \multirow[t]{2}{*}{ Events } & \multirow[t]{2}{*}{ Year } & \multicolumn{4}{|c|}{ Evolution in income \% (2005-2008) } \\
\hline & & $\begin{array}{l}\text { Stable/lower } \\
\text { (< R\$150.00) }\end{array}$ & $\begin{array}{c}\text { Higher } \\
(<\mathrm{R} \$ 150.00)\end{array}$ & $\begin{array}{l}\text { Stable/lower } \\
\text { (> R\$150.00) }\end{array}$ & $\begin{array}{c}\text { Higher } \\
\text { (> R\$150.00) }\end{array}$ \\
\hline \multicolumn{6}{|l|}{ Violence in the family } \\
\hline Siblings fought to the point of hurting & 2005 & 31.2 * & 26.5 * & 21.2 * & 19.2 * \\
\hline each other & 2008 & 18.6 & 17.6 & 13.6 & 7.3 \\
\hline Serious physical violence by mother & 2005 & 55.3 * & 57.0 * & $54.6 *$ & $61.7 *$ \\
\hline against child & 2008 & 31.4 & 40.4 & 33.3 & 40.9 \\
\hline Serious physical violence by father & 2005 & 22.7 * & 20.8 * & 25.5 * & $28.1 *$ \\
\hline against child & 2008 & 17.1 & 14.3 & 13.0 & 22.2 \\
\hline Serious physical violence by mother & 2005 & 24.3 & 12.1 * & 8.9 * & 14.5 * \\
\hline against father & 2008 & - & 6.1 & 5.3 & 1.8 \\
\hline Serious physical violence by father & 2005 & 16.7 & 17.0 * & 8.4 & 13.1 * \\
\hline against mother & 2008 & - & 6.7 & 7.9 & 1.7 \\
\hline
\end{tabular}

* Comparison of life events between 2005 and 2008 for each income group.

improved living and health conditions, especially if such economic advances are not maintained. In general, monetary increments are spent on basic and immediate products and needs that do not substantially affect the families' social position. In addition, the socioeconomic context of the communities in which the families live was not modified structurally from 2005 to 2008 (to the point of substantially altering the existing risk situation). One could further hypothesize that the international financial crisis in 2008, which caused financial losses and a slow-down in economies around the world, may have jeopardized a more favorable scenario, hampering the situation of the families studied here. However, the intervention by the Brazilian state and the supervision of the country's banking sector by government agencies appears to have mitigated the crisis, protecting the population, especially the poorest 18,19 .

Brazil's metropolitan areas display a concentration of families in poverty, but which display subtle differences from the poverty of decades ago ${ }^{1}$. There are also gradations in poverty that can impact the representations of this social condition.

The reduction in the psychosocial risk factors affecting families over time may partially reflect the improvement in their living standard, but it also results from the children's developmental stage, which can both protect them from some situations and expose them to others. Such is the case of the increase in the number of accidents from 2005 to 2008, since the children were older in the latter year, spending more time on the streets and thus more vulnerable to hazards in the surrounding community. Importantly, the reduction in family violence during the target period may be analyzed from two angles: (1) as a real decrease resulting from the children's older age, which would tend to protect them from physical violence in the home and (2) intervention from the first wave in the study, since the parents/guardians were aware that one of the study's objectives was to investigate the effects of violence on child development, which may have led the parents/guardians to either reflect on the relationship and family violence or to omit such facts from the interviewers.

Regardless of other explanations, psychosocial risk factors are more present in a setting with precarious socioeconomic conditions. A study in public and private schools in São Gonçalo showed that students from social strata A and $B$ experienced significantly fewer adverse life events than those from strata C, D, and E 6 .

This scenario shows the extent to which lowincome groups are exposed to situations that are potentially harmful to their health. Low socioeconomic status not only exposes individuals to greater acute stress (more disastrous and with negative short-term effects), but also significantly increases chronic stress (less damaging, but with long-term consequences) 6 . A cascade of exposure and adverse experiences is commonly associated with social disadvantage, especially when it begins early in life and accumulates over the years. Early experiences can have residual health effects for many years to come. Evans \& Kim 7 show how multiple risk accumulated over 
life can mediate relations between individuals' socioeconomic status and health gradient, since the more adverse experiences an individual accumulates, the greater the physical and psychosocial harm. The same authors also stated that children from low-income families experience three times more stressful events than their more affluent peers.

When families that have increased their income and consumption remain in a social setting that continues to expose them to multiple risks, it decreases their likelihood of overcoming or decreasing the level of emotional stress. Another relevant aspect is the higher self-esteem of families whose per capita income increased during the target period, which is indicative of a strong interface between this characteristic and their living conditions. According to a similar study by Assis et al. 6, self-esteem is higher among adolescent schoolchildren in São Gonçalo belonging to higher and middle-income strata as compared to those from low-income strata.

However, this issue is still controversial in the literature $16,20,21$. The individual attributes that comprise self-esteem are known to be shaped in daily relations since early childhood 22 . In addition, established power relations and social norms also play an important role in the process of acquiring self-esteem, because it is based on such relations that persons evaluate their behavior and their experiences with success and failure, where one's socioeconomic condition can make a major contribution ${ }^{21}$.

Observation of the relationship between selfesteem and socioeconomic status is important, because this attribute is known to mediate one's perception of life situations, and may for example interfere in the assessment of a given fact as more or less threatening or dangerous. It is also relevant because of its mediation with health status and social competence 22,23,24. Concerning this aspect, Schnittker et al. 24 made two observations: (1) greater social competence reduces the association between income/education and the total number of chronic conditions by $12 \%$ and $4 \%$, respectively and (2) higher self-esteem reduces the association between income/education and the accumulation of adverse conditions by $13 \%$ and $5 \%$, respectively.

We conclude by highlighting the financial increment experienced by these families during the three-year period, especially due to prevailing public policies. However, this increment: (a) does not, by itself, guarantee the improvement of living and health conditions and the reduction in risk exposure for these families (i.e., structural problems persist) and (b) shows signs of a positive impact on basic and individual aspects, like self-esteem, which plays an important role in the perception of living situations. Information from longer follow-up of the families could contribute to a more conclusive debate in the future.

A relevant limitation of the study is that it was restricted to lower-income socioeconomic strata, thus impeding comparative analyses with higher-income groups. Another limitation was the descriptive approach, which bypasses the evaluation of multiple levels of influences and the interaction between the target questions. 


\section{Resumo}

O objetivo deste artigo é avaliar os reflexos do recente crescimento econômico brasileiro sobre o rendimento monetário, o padrão de consumo familiar e os riscos em que vivem famílias da rede pública do Ensino Fundamental do Município de São Gonçalo, Rio de Janeiro, Brasil. São analisadas as seguintes informações sobre as famílias de 447 crianças que participaram de duas ondas de estudo longitudinal: estrato social, renda familiar per capita, evolução de renda no período e fatores psicossociais. Os resultados indicam incremento financeiro em $74,8 \%$ das famílias, acompanhado de aumento no consumo de bens materiais e no acesso a serviços de saúde. Esse crescimento não pode ser tomado como garantia de melhoria nas condições de vida e saúde, já que é gasto com a aquisição de produtos e necessidades básicas que não chegam a afetar substancialmente a forma de inserção social em que vivem as famílias. Os fatores de risco psicossociais mostraram-se frequentes, porém decrescentes nas famílias estudadas, o que pode refletir a melhoria da situação de vida familiar ou ser decorrente da etapa do desenvolvimento infantil.

Crescimento e Desenvolvimento; Condições Sociais; Criança; Fatores de Risco

\section{Contributors}

All the authors participated in the article's elaboration.

\section{Acknowledgments}

The study received funding from CNPq and FAPERJ.

\section{References}

1. Neri MC. Miséria e a nova classe média na década da igualdade. http://www.fgv.br/cps/desigualda $\mathrm{de} /$ (accessed on 12/May/2010).

2. Torres HG, Bichir RM, Carpin TP. Uma pobreza diferente? Mudanças no padrão de consumo da população de baixa renda. Novos Estudos CEBRAP 2006; 74:17-22.

3. Neri MC. A pequena grande década: crise, cenários e a nova classe média. http://www.fgv.br/cps/ c2010/ (accessed on 12/May/2010).

4. Cohen S, Janicki-Deverts D, Chen E, Matthews KA. Childhood socioeconomic status and adult health. Ann N Y Acad Sci 2010; 1186:37-55.

5. Buss PM, Pellegrini Filho A. A saúde e seus determinantes sociais. Physis (Rio J.) 2007; 17:77-93.

6. Assis SG, Pesce RP, Avanci JQ. Resiliência: enfatizando a proteção na adolescência. Porto Alegre: Editora Artmed; 2006.
7. Evans GW, Kim P. Multiple risk exposure as a potential explanatory mechanism for the socioeconomic status-health gradient. Ann N Y Acad Sci 2010; 1186:174-89.

8. Rutter M. Stress, coping, and development. In: Garmezy N, Rutter M, editors. Stress, coping, and development. New York: McGraw-Hill; 1993; p. 1-41.

9. Sameroff A, Seifer R, Zax M, Barocas R. Early indicators of developmental risk: Rochester longitudinal study. Schizophr Bull 1987; 13:383-94.

10. Garmezy N. Children in poverty: resilience despite risk. Psychiatry 1993; 56:127-36.

11. Adler NE, Stewart J. Health disparities across the lifespan: meaning, methods, and mechanisms. Ann N Y Acad Sci 2010; 1186:5-23. 
12. Matthews KA, Gallo LC, Taylor SE. Are psychosocial factors mediators of socioeconomic status and health connections? A progress report and blueprint for the future. Ann N Y Acad Sci 2010; 1186:146-73.

13. Straus MA. Measuring familiar conflict and violence: The Conflict Tactics (CT) Scales. J Marriage Fam 1979; 41:75-88.

14. Hasselmann MH, Reichenheim ME. Adaptação transcultural da versão em português da Conflict Tactics Scales Form R (CTS-1), usada para aferir violência no casal: equivalência semântica e de mensuração. Cad Saúde Pública 2003; 19:1083-93.

15. Kahn T, Bermergui C, Yamada E, Cardoso FC, Fernandes F, Zacchi JM, et al. O dia-a-dia nas escolas (violências auto-assumidas). São Paulo: Instituto Latino-Americano das Nações Unidas para a Prevenção do Delito e Tratamento do Delinqüente/ Instituto Sou da Paz; 1999.

16. Rosenberg M. Society and the adolescent self-image. Princeton: Princeton University Press; 1989.

17. Avanci JQ, Assis SG, Santos NC, Oliveira RVC. Adaptação transcultural de escala de auto-estima para adolescentes. Psicol Reflex Crit 2007; 20: 397-405.
18. Mazzucchelli F. A crise em perspectiva: 1929 e 2008. Novos Estudos CEBRAP 2008; 82:57-66.

19. Dulci OS. Economia e política na crise global. Estud Av 2009; 23:105-19.

20. Mruk C. Self-esteem: research, theory, and practice. New York: Springer Publishing Co.; 1995.

21. Callero PL. The sociology of the self. Annu Rev Sociol 2003; 29:115-33.

22. Bosma H, Schrijvers C, Mackenbach JP. Socioeconomic inequalities in mortality and importance of perceived control: cohort study. BMJ 1999; 319:1469-70.

23. Gallo LC, de los Monteros KE, Ferent V, Urbina J, Talavera G. Education, psychosocial resources, and metabolic syndrome variables in Latinas. Ann Behav Med 2007; 34:14-25.

24. Schnittker J. Psychological factors as mechanisms for socioeconomic disparities in health: a critical appraisal of four common factors. Soc Biol 2004; 51:1-23.

Submitted on 14/May/2010

Final version resubmitted on 21/Oct/2010

Approved on 03/Jan/2011 